\title{
Politik Islam Era Gus Dur: Antara Mitos dan Realitas
}

\author{
Bambang Cipto
}

Since the based-on religion parties emerge again in the Indonesia political stageespecially when they succeeded in electing GUS DUR as the president, Moslem society has a very hard consequence. Abdul Rahman Wahid who has a very specific style in solving problems and who in the same time is considered as the protector of the minority becomes a certain dilema figure for Moslems. He brings a hope for moslems to give them more endorsement, but unfortunately GUS DUR is not an easy man to dictate. The writer of this book views that the problem is mainly because of the shackle institution around the presidency as well as GUS DUR's unpredictable political steps. He were standing between the maintenance of democracy in one side and the future of this state in other side.

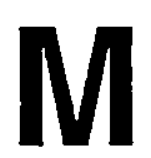

enjelang dan sesudah terbentuknya pemerintahan baru di bawah Abdurrahman Wahid kekuatan Islam tampil sangat meyakinkan. Partai-partai Islam di bawah payung poros tengah yang dimotori Amien Rais dari PAN memainkan peran sangat menentukan dalam drama pemilihan Ketua MPA, DPR, dan presiden. Rangkaian peristiwa beberapa waktu terakhir dengan gamblang memperlihatkan betapa besar dan menentukan pe ngaruh kekuatan partai-partai Islam.

Sesudah presiden terpilih kembali partaipartai Islam dengan tangkas ikut menentukan susunan kabinet baru. Dalam proses tersebut manuver Amien Rais dan tokohtokoh partai Islam lain tampak dengan jelas menentukan komposisi kabinet baru. Mo men ini mungkin hanya berlangsung sekali dalam tiga puluh tahun terakhir. Pada mingguminggu pertama presiden Gus Dur sedemikian akomodatif terhadap partai-partai Islam sehingga muncul kebanggaan dan harapan dari kalangan Islam di Indonesia.
Memasuki minggu-minggu berikutnya bandul yang diayunkan poros tengah mulai menghadapi cobaan serius. Gus Dur dengan tenang memutuskan untuk segera meninggalkan Indonesia dan melakukan kunjungan kenegaraan ke beberapa negara Asia. Bahkan sambil berobat ke Amerika ia juga melakukan kunjungan tidak resmi ke kediaman presiden Clinton. Selama kunjungan berlangsung sesungguhnya mulai muncul beberapa kritik terhadap manfaat kunjungan tersebut. Sebagian berharap agar presiden Gus Dur mengakhiri kunjungan keluar negeri dan memusatkan perhatian ke persoalan-persoalan dalam negeri yang semakin berkecamuk.

Sekalipun demikian rangkaian kunjungan ini tidak banyak menimbulkan oposisi dari kalangan masyarakat. Baru pada saat Gus Dur menyatakan akan membuka hu bungan dagang dengan Israel oposisi muncul dari kalangan Islam di tanah air. Oposisi ini kemudian meluas hingga ke daerahdaerah yang akhirnya memaksa Gus Dur 
menunda rencananya untuk membuka hu bungan dagang dengan Israel. Hingga tahap ini Gus Dur masih tampak tegar dalam menghadapi tuntutan dari berbagai kelompok di dalam maupun di luar pemerintahan baru. Akan tetapi eskalasi konflik berdarah di Ambon dan Halmahera dan tidak menentunya kondisi politik di Aceh membuat kebijaksanaan Gus Dur sangat tidak efektif. Akibatnya, popularitas Gus Dur pun merosot drastis. Bagaimana semua ini berpengaruh terhadap politik Islam di Indonesia kini dan esok?

Pada saat sistem multipartai dinyatakan berlaku oleh pemerintahan Habibie muncul harapan besar bahwa liberalisasi sistem partai ini akan memberi peluang lebih besar bagi pertumbuhan politik Islam di Indonesia. Paling tidak ada harapan bahwa partaipartai Islam akan memainkan peran lebih berarti dibanding dalam era Suharto yang sangat represif terhadap kekuatan politik Islam. Bahkan sesungguhnya beberapa partai Islam sangat berharap masih akan mendapatkan akses politik yang dinikmatinya sepanjang pemerintahan Habibie yang rajin mendekati beberapa kekuatan politik Islam. Oleh karena itu tidak semua partai Islam menentang secara frontal kepemimpinan Habibie, kecuali beberapa partai yang cukup besar dan pada akhirnya menentukan pergantian rejim baru lewat sidangsidang di MPR dan DPR.

Kesediaan Habibie mengundurkan diri dari pencalonan presiden membuat kalkulasi kekuatan politik Islam mengalami pergeseran-pergeseran serius. Perubahan ini sesungguhnya memberi kesempatan besar bagi Megawati sebagai eksponen nasionalis sekuler untuk memenangkan persaingan merebut kursi kepresidenan dalam sidang umum MPR. Namun jauh sebelum sidang umum berlangsung Amien Rais telah menggulirkan isu poros tengah yang pada harihari terakhir mengajukan Gus Dur sebagai calon presiden dari poros tengah yang sesungguhnya hanya berupa fraksi informal yang tidak memiliki kekuatan resmi apa pun dalam tubuh MPR.

Merosotnya popularitas Golkar dan mundurnya tokoh panutan Golkar dalam pencalonan presiden mendorong partai ini untuk segera membangun koalisi dengan partai lain yang sejalan dengan kepentingan mereka. Rendahnya popularitas TNI juga menjadi alasan kuat mengapa TNI memilih tidak mengajukan nama secara terbuka dari fraksinya. TNI ingin tetap bersih dari persaingan tanpa kehilangan kesempatan untuk ikut menentukan penyusunan kabinet.

Kondisi ini membuat kekuatan politik Islam di MPR dan DPR mendukung altematif poros tengah yang dilansir Amien Rais. Sekalipun dengan penuh keragu-raguan mereka kemudian sepakat untuk mendukung ketua PAN selaku ketua MPR. Menje lang pemilihan presiden partai-partai Islam dan partai berbasis Islam semakin solid dalam mendukung manuver poros tengah yang mencalonkan Gus Dur dari PKB. Kekuatan Islam sukses mengantarkan Gus Dur dalam pemilihan presiden.

\section{Kabinet Kolegial}

Cukup besar harapan kekuatan politik Islam agar pemerintahan Gus Dur yang ter pilih secara demokratis akan memberikan manfaat sebesar-besarnya bagi seluruh umat Islam. Paling tidak itulah yang tercermin dari keterlibatan Ketua PAN, Ketua PPP, Ketua PBB dan Ketua PK senta PKB dalam proses penentuan komposisi kabinet baru. Keterlibatan mereka untuk pertama kalinya selama tiga dasa warsa terakhir dalam pembentukan kabinet merupakan momen historis yang tak terelakkan.

Sekalipun demikian apa yang terjadi dalam pembentukan kabinet tersebut merupakan eksperimen yang cukup mahal. Kabinet dibentuk di tengah ancaman para 
pendukung Megawati yang sangat kecewa bahwa calon mereka gagal menduduki kursi presiden. Oleh karena itu reaksi alamiah yang muncul adalah bagaimana membentuk kabinet yang dapat meredam kerusuhan yang diperkirakan akan meledak dengan hilangnya kesempatan Megawati sebagai presiden. Di samping Gus Dur sendiri dikenal sangat dekat dengan Megawati sehingga sekalipun $\mathrm{PDI}$ perjuangan tidak mendukung pencalonan Gus Dur sebagai presiden maka partai ini mendapatkan dua hal yang strategis. Kedua posisi tersebut adalah wakil presiden dan beberapa kursi kabinet yang sangat menentukan.

Pemerintahan baru yang sangat dipengaruhi oleh reaksi presiden selaku "representasi" Islam terhadap ancaman kerusuhan sesaat ini kemudian dikenal sebagai kabinet kompromistis atau kabinet balas budi. Dalam kajian perbandingan politik bentuk pemerintahan yang mirip dengan kabinet Gus Dur ini adalah pemerin tahan kolegial. Pemerintahan kolegial tumbuh di tengah masyarakat yang sangat heterogen. Dalam masyarakat yang sangat pluralistis dengan perbedaan ekonomi yang cukup menyolok model pemerintahan yang dibangun berdasarkan kompetisi penuh antar partai seringkali merugikan golongan minoritas. Oleh karena beberapa negara dengan kondisi masyarakat yang sangat heterogen justru memilih untuk menerapkan logika kolegialitas dan mengesampingkan kompetisi penuh.

Arend Lijphart misalnya membagi demokrasi ke dalam dua bentuk demokrasi, yakni demokrasi Westminster dan demokrasi konsensus. Demokrasi Westminster' yang diprakarsai oleh model pemerintahan Inggris mengutamakan kompetisi dari dua partai utama. Amerika pada dasarnya merupakan model Westminster yang telah mengalami mutasi politis. Akan tetapi esensi demokrasi Amerika tetap, yakni, pemerintahan oleh satu partai yang memenangkan persaingan dalam pemilihan kepala eksekutit.

Model-model kompetisi penuh sebagaimana di Amerika dan Inggris seringkali merugikan golongan minoritas yang tak pernah mampu memenangkan setiap pemilihan yang didominasi oleh partai-partai besar. Dalam jangka panjang ketidakpuasan minoritas dapat berubah menjadi gerakangerakan separatis atau disintegratif yang pada akhirnya dapat merugikan keutuhan nasional. Sedemikan seriusnya ancaman yang dapat ditimbulkan oleh model pemerintahan kompetitif sehingga beberapa masyarakat yang sangat pluralistik meninggalkan pilihan demokrasi kompetitif dan memilih membangun demokrasi konsensus dalam bentuk pemerintahan kolegial.

Oleh karena itu bentuk demokrasi yang kedua adalah demokrasi konsensus. Model pemerintahan ini merupakan konsensus dari partai-partai politik pemenang pemilu dengan tidak mengabaikan golongan minoritas. Karena pada demokrași konsen sus memang ada jaminan bahwa partai kecil akan memiliki wakilnya di dalam pemerintahan. Model ini memang banyak diterapkan di Swiss, Belanda, Nonwegia, Jepang, Jerman, Italia, dan Kanada."

Di samping menguntungkan partai-partai minoritas model pemerintahan kolegial juga pada umumnya sangat akrab dengan kepentingan-kepentingan rakyat kecil seperti pengangguran. Di negara-negara kolegial, yang banyak diterapkan oleh negara di

'Istilah Westminster diambil dari nama gedung Parlemen Inggris.

2 Thomas A. Baylis, "Pemerintahan Oleh Komite: Kepemimpinan Kolegial di Negaranegara Maju," dalam Arend Lijphart (ed), Sistem Pemerintahan Parlementer dan Presidensial, Jakarta, PT RajaGrafindo Persada, 1995, hal. 246. 
kawasan Eropa Utara, tingkat pengangguran lebih rendah dibanding Amerika yang dipimpin oleh model demokrasi kompetitif. Hubungan kemitraan yang akrab antara pemerintah dan rakyat membuat tingkat pemogokan yang dilakukan kaum buruh juga rendah dibandingkan pemogokan di Amerika.

Dengan kata lain, manuver partai-partai Islam baik dalam pemilihan presiden maupun pembentukan kabinet sesungguhnya menempatkan kekuatan Islam dalam posisi menentukan dalam proses penataan politik di tengah transisi saat ini. Persoalannya adalah sejauh mana kontribusi itu menciptakan kondisi yang menguntungkan bagi umat Islam secara keseluruhan? Dalam perjalanannya ternyata model pemerintahan kolegial ini ternoda oleh kelemahan-kelemahan institusional yang.bersifat tak terelakkan dan personalitas presiden Gus Dur yang tidak cukup siap untuk membangun budaya demokrasi baru lewat posisinya selaku kepala eksekutif.

\section{Ancaman Bebek Dungu}

Serangkaian kejadian yang berlangsung selama bulan-bulan pertama pemerintahan Gus Dur pada akhimya membuka kenyataan bahwa selaku kepala eksekutif presiden tampak ragu dalam menjalankan kebijaksanaan politiknya. Pertama, Gus Dur masih sering menyuarakan kebiasaan lama selaku pejuang demokrasi jalanan sehingga sulit membedakan statusnya antara pejuang demokrasi dan kepala eksekutif yang memimpin sebuah pemerintahan resmi dengan jumlah pendudukan lebih dari 200 juta manusia.

Kedua, ada kesan Gus Dur kesulitan dalam menyusun agenda politiknya sendiri sehingga muncul berbagai masukan dari luar yang pada akhirnya membuat proses pembuatan keputusan sangat lamban dengan akibat sangat serius. Secara khusus persoalan daerah Aceh dan Ambon tidak tampak menjadi perhatian utama Gus Dur selaku presiden. Gus Dur lebih banyak melakukan manuver-manuver politik ringan yang tidak teriokus pada persoalan yang sesungguhnya. Padahal persoalan yang muncul saat ini bergerak sangat cepat. Bahkan sangat jauh lebih cepat dari per soalan-persoalan yang bermunculan pada saat rejim Suharto berdiri pada akhir dekade 60-an yang lalu.

Ketiga, kelambanan pemerintah bahkan kemudian diperburuk dengan pergantian anggota kabinet yang kurang menghargai suara dari mayoritas partai-partai pendukungnya baik di MPR maupun DPR. Jika kebiasaan mengabaikan partai-partai Islam sebagai pendukung utama Gus Dur dalam pemilihan presiden ini terus dipertahankan maka bukan tidak mungkin akan muncul persoalan serius dalam hubungan antara Gus Dur dan basis dukungannya di legislatif. Sayang, bahwa reaksi Gus Dur terhadap basis pendukungnya cenderung memperlebar kesenjangan tersebut.

Perilaku Gus Dur yang berusaha meyakinkan publik atas otonominya dari tekanan-tekanan partai-partai Islam dan partai berbasis massa Islam menimbulkan pertanyaan atas masa depan politik Islam di Indonesia. Apakah kekuatan Islam masih akan bortahan dalam beberapa tahun mendatang atau akan semakin terpojok oleh manuver-manuver presiden yang cenderung menjauh dari kekuatan Islam?

Posisi Gus Dur sendiri saat ini sudah mendekati gejala bebek dungu sebagaimana dialami presiden di beberapa negara Amerika Latin. Prediksi para ahli kepresidenan bahwa kombinasi antara parlemen yang terdiri dari multipartai dan presiden akan menghasilkan presiden yang lemah ternyata mulai menunjukkan tanda-tanda akan terbukti pula di Indonesia. Kombinasi ini memang cukup buruk karena dalam sistem 
presidensialisme maka presiden sulit dibubarkan oleh parlemen. Dikala presiden tidak lagi populer di kalangan parlemen maka seharusnya parlemen mengajukan mosi tidak percaya untuk menjatuhkan presiden. Akan tetapi sistem presidensialisme menolak logika tersebut sebab sistem ini menghendaki presiden menyelesaikan seluruhnya masa jabatannya tanpa memperdulikan dirinya populer atau tidak populer.

Dalam hal ini sesungguhnya popularitas Gus Dur di mata MPR dan DPR mungkin tidak setinggi pada saat ia dipilih dalam SU MPR. Baik Ketua MPR maupun DPR sudah berusaha untuk mengeluarkan per nyataan yang keras agar presiden segera mengambil tindakan efektif untuk menyelesaikan kasus Ambon dan Aceh. Namun reaksi presiden tampak lambat dan mengecilkan persoalan sesungguhnya. Presiden bahkan cenderung menanggapi secara emosional kritik-kritik tajam dari publik yang dalam alam demokrasi nyaris tak berarti karena ia terpilih secara resmi. Jika hubungan ketegangan antara MPR/DPR dan presiden ini terus berkembang sementara MPR/DPR tidak dapat berbuat sesuatu untuk menekan presiden maka presiden akan terjungkal kedalam gejala bebek dungu. Keterlibatan ketua MPR Amien Rais dalam rapat akbar di Jakarta menjelang Lebaran yang lalu mencerminkan betapa sulitnya melakukan kritik secara kelembagaan terhadap Gus Dur.

Dalam pemerintahan kolegial oposisi oleh badan legislatif sangat diperlukan untuk menjaga agar kekuasaan eksekutif tidak menggelembung dan berubah menjadi tirani. Oleh karena kritik dari legislatif harus ditanggapi sebagai peringatan dari basis pendukung eksekutif. Persoalannya menjadi sangat pelik karena Gus Dur lebih percaya kepada kekuasaan presiden yang dimilikinya daripada partai-partai politik di bidang legislatif yang memberinya legiti- masi untuk membentuk pemerintahan. Ini persoalan inti dari kekuasaan presiden yang dibentuk dari sistem multipartai. Legitimasinya yang sedemikian kuat sesungguhnya merupakan sebuah ilusi. la setiap saat dapat dijatuhkan oleh legislatif sebagaimana dalam pemerintahan parlementer. Akan tetapi karena konstitusi melarang pembubaran pemerintah oleh MPR/DPR maka ia akan melakukan apa pun untuk mempertahankan kekuasaannya selaku presiden. Dalam jangka panjang tradisi presidensialisme imajinatif ini akan mendorong kembalinya kekuasaan otoriter.

Perilaku politik Gus Dur juga mencerminkan apa yang dikemukakan oleh Timothy J. Power sebagai irasionalitas partai-partai politik baru. ${ }^{3}$ Gus Dur tampi! sebagai presiden yang gugup dan terperangah oleh besarnya kekuasaan konstitusional yang diperolehnya tanpa melalui perjuangan kelembagaan yang cukup lama dan teruji. Pada saat ia memulai menjalankan kekuasaan tersebut ia lupa bahwa hubungan dirinya dengan partai-partai pendukungnya di MPR/DPR tidaklah kohesif karena bersifat tiba-tiba. Sehingga ia dengan tanpa beban merekrut tokoh-tokoh Forum Demokrasi yang tidak memiliki warna partai politik apa pun. Padahal kekuasaan presiden Indonesia sama sekali berbeda dengan kekuasaan presiden Ame

${ }^{3}$ Timothy J. Power, "Parties, Puppels, and Paradoxs: Changing Attitudes Toward Party Institutionalization in Post-Aultoritarian Brazil, Party Politics, (April 1997). Power menyebutkan bahwa masyarakat Jerman yang terlalu lama mengalami marjinalisasi - politik akan mengalami ketergagapan pada saat membangun partai-partai baru. Oleh karena itu hubungan antar partai pun menjadi tidak kohesif satu sama lain. Kondisi serupa juga terjadi di Brazil sehingga partai-partai menjadi tidak rasional dalam bertindak. 
rika yang dipilih secara langsung yang memang sangat legitimate untuk mengambil penasehat dari teman-teman lamanya. Kecenderungan ini sudah tentu berlawanan dengan logika kolegialisme yang menuntut kesediaan eksekutif untuk mendengarkan sepenuhnya suara partai politik di badan legislatif. Dalam pemerintahan kolegial murni pada umumnya hanya orang-orang patai yang berhak memásuki kabinet.

Persoalan ini akan menjadi sangat serius bagi kekuatan politik Islam karena dengan demikian apa yang selama ini diyakini bahwa Islam mampu memberikan kontribusi dalam penataan politik nasional ternyata gagal membuktikan janji tersebut. Gus Dur sendiri sudah tentu memiliki alasan yang sangat kuat mengapa ia tampak lambat dan justru menempuh kebijaksanaan yang tidak populer seperti melakukan pergantian anggota kabinet. Salah satu alasan yang mungkin menghalangi langkah Gus Dur adalah unsur militer dalam tubuh pemerintahan saat ini. Kondisi ini membuat pemerintahan sipil berjalan d itempat sekaligus menunjukkan betapa lemahnya koordinasi antar kekuatan politik sipil. Dalam arti bahwa kekuatan politik sipil gagal membangun sebuah koalisi ketat untuk mengisolir tentara dari politik. Sebaliknya tentara mampu secara efektif mencerai-beraikan kekuatan-kekuatan politik sipil khususnya di kalangan partai-partai Islam.

Berdasarkan pertimbangan-pertimbangan di atas maka jelas bahwa kekuatan politik Islam masih menghadapi tantangan serius di masa depan. Tantangan ini berupa konsolidasi antar partai dan antara partai dan kekuatan Islam di luar partai. Bahkan di masa depan partai-partai Islam harus mampu menjalin kerjasama dengan partai lain yang benar-benar memiliki kredibilitas dan integritas tinggi sebagai rekanan politik.

\section{Harapan dari Poros Tengah}

Di kalangan umat Islam tidak sedikit yang memandang poros tengah dengan sebelah mata khususnya mereka yang memandangnya sèbagai bentuk tantangan baru bagi kekuatan politik yang mapan. Sekalipun demikian sejak SU MPR hingga kini poros tengah selalu tampil dengan kreasi-kreasi politik baru yang belum mendapat tandingan yang seimbang baik dari kalanga Islam maupun nasionalis sekuler, kecuali militer. Poros tengah mampu menjaga diri sehingga tidak mudah tenggelam dalam rutinitas politik yang sering berkembang menjadi konservatisme sebagaimana dialami Golkar pada masa Suharto.

Poros tengah tampaknya masih harus menciptakan kembali berbagai kreatifitas politik untuk menjaga momentum popularitas politik Islam. ${ }^{4}$ Sudah tentu tantangan ini akan membuat poros tengah mengalami saat-saat sulit. Upaya poros tengah untuk melakukan kritik tajam terhadap pemerintahan-Gus Dur adalah sebuah eksperimen yang cukup mahal. Tantangan dari dalam tubuh umat Islam sendiri terhadap eksperimen tersebut selalu lebih besar daripada kemudahan yang diharapkan. Pada saat

4Perilaku politik poros tengah selama ini misip dengan prediksi kalangan ahli manajemen internasional yang memperkirakan bahwa pada era milenium ketiga akan muncul kepemimpinan baru sebagaimana diprediksi Mark A. Abramson sebuah artikelnya: "Leadership for the Future: New Behaviours, New Roles, and New Attitudes," The Public Manager, (Spring 1997). Ciri-ciri tersebut, antara lain, (1) kesediaan berbagi kepemimpinan; (2) berperan sebagai komunikator; (3) katalisator perubahan; (4) mengembangkan kemampuan mitra yang lain; (5) bekerja berdasarkan knowledge, ideas, dan inlormation (knowledge workers); (6) menolak rintangan hirarkis. 
reformasi berlangsung pun sebagian besar umat Islam pada umumnya agak ketakutan kecuali beberapa gelintir tokoh reformisnya.

Kondisi politik yang tidak menentu di Ambon, Halmahera dan Aceh saat ini menuntut kembali kepemimpinan umat Islam. Mungkin hanya poros tengah yang masih bernyali untuk melakukan terobosan politik. Fraksi-fraksi lain baik di MPR maupun DPR pada umumnya kurang bersemangat untuk melakukan kritik tajam. Mereka sangat percaya pada budaya menunggu hingga badai reda dan selalu siap untuk mengumpulkan dan menikmati ikan-ikan segar setelah badai berlalu. Poros tengah sebaliknya selalu siap menerjang badai betapapun kerasnya.

Persoalan dasar bagi umat Islam adalah meyakinkan semuanya bahwa kehidupan politik selalu penuh dengan badai yang setiap saat menerjang kehidupan manusia. Budaya menghadang badai mungkin sangat sedikit dikenali elit Islam di Indonesia. Sehingga sekali lagi hanya segelintir pemimpin Islam yang selalu bersedia untuk menyingsingkan lengan baju dan siap melawan terkaman badai politik.

Tidak meratanya semangat demokrasi di kalangan elit kepemimpinan Islam membuat politik Islam di Indonesia sulit berkembang luas. Tantangan terberat bagi umat Islam barangkali adalah meningkatkan sosialisasi nilai-nilai Islam yang mendukung pertumbuhan demokrasi di Indonesia khususnya di kalangan lapis elit Islam. Tokoh-tokoh seperti Nurcholis Madjid dan Amien Rais terlalu sedikit dibandingkan dengan ratusan juta umat yang pada umumnya sangat sederhana dan sering dimanipulasi oleh segelintir elitnya sendiri untuk kepentingan mereka.

Akhirnya, harapan kepada poros tengah untuk tetap mempertahankan semangat inovasi politiknya memang perlu mendapat dukungan dari kelompok non-partai yang memiliki kredibilitas sebanding. ${ }^{5}$ Kebutuhan ini sangat mendesák karena kekuatan konservatif tampaknya sedang membentuk diri dan mencari saat yang paling tepat untuk membinasakan masa depan poros tengah. Apakah kekuatan politik Islam termasuk di dalamnya ormas-ormas Islam menyadari kebutuhan tersebut atau justru menganggap agenda tersebut tidak lebih dari urusan poros téngah sendiri? Bukan tidak mungkin bahwa poros tengah masih harus bermain tunggal dalam jangka lama dan ini berarti bahwa umat Islam memang belum siap sepenuhnya untuk menjadi kontributor utama dalam era transisi menuju penataan kembali politik nasional paskaSuharto. Adalah tugas kalangan elit intelektual dan keagamaan untuk mengubah kondisi minus ini menjadi kondisi plus dengan mendorong terciptanya individu dan kelompok berbasis Islam yang memiliki motivasi tinggi, kreatif dan berjiwa menerobos ke depan.

sPeter J. Anderson, The Global Politics of Power, Justice and Death: An Introduction to International Relations, London: Routledge, 1996. Anderson mengawali studi hubungan internasional yang mulai menekankan peran signifikan organisasi keagamaan dalam proses pengambilan politik luar negeri Amerika. Secara implisit studi ini mengacu pada semakin pentingnya peran organisasi keagamaan dalam proses politik nasional sebagai sesuatu yang tak terelakkan. Dalam konteks inilah sesungguhnya ormas-ormas keagamaan di Indonesia perlu melakukan revisi atas persepsi mereka tentang keberadaan dan masa depan politik poros tengah dalam konteks transisi politik demokrasi di Indonesia. 
Topik: Politik Islam Era Gus Dur: Antara Mitos dan Realitas, Bambang Cipto

\section{Daftar Pustaka}

Abramson, A. 1997, Leadership for the fu- Liapart, Arend (ed), 1995, Sistem ture: New Behavioris, New Roles, and Ner Attitodes, The Publik Manager, Spring - 1997.

Pemerintahan Parlementer dan Presidensial, PT. Ragu Grafindo Perkasa, Jakarta

Anderson, Perter J, 1996, The global Politics of Power, justice and Death: An Introduction to International Pelation, Routledge, London.

Power, Timoly J, 1997, Parties, Puppets, and Paradoxs: changing Attitudes Toward Party Institutionalization in Post-Authoritarian Brazil, Party Politics, April - 1997. 